\title{
Integration and Use of the Interdisciplinary Knowledge in the Field of Spatial and Economic/Business Sciences
}

Polona Tominc ${ }^{1}$, Vit Paszto ${ }^{2}$, Samo Bobek ${ }^{3}$ and Simona Sternad Zabukovšek ${ }^{3}$ 'University of Maribor, Faculty of Economics and Business, Department of Quantitative Economic Analyses

${ }^{2}$ Palacký University Olomouc, Faculty of Science, Department of Geoinformatics ${ }^{3}$ University of Maribor, Faculty of Economics and Business, Department of E-Business

\section{Abstract}

This research arises from the importance of integrating knowledge of economicl business and spatial sciences for graduates who must think and act in interdisciplinary contexts. The systematic literature review revealed that this interdisciplinary field is richly present in original scientific research, and is undoubtedly topical and worthy of research efforts. The main objective of this paper is to analyze important factors that contribute to the attitudes of students towards interdisciplinary knowledge, and factors that shape their intentions to use and integrate this knowledge in the future. The conceptual model formed was tested using structural equation modeling (SEM). Research results confirm the importance of integrating economic/business and spatial sciences' knowledge, for graduates. As presented in the paper, results of the study have important implications for higher education institutions, for reform and update of their study programs, as well as for educators in the field of spatial sciences and economic/business sciences, in research and in education.

Key words: acceptance model; geoinformatics; structural equation modeling.

\section{Introduction}

There is no doubt that students nowadays need to think and work in interdisciplinary contexts (Shen, Sung, \& Zang, 2015). In several situations, the cross-disciplinary scientific approach, which combines management sciences and natural sciences, is 
important. Examples can be found in natural resources management (Robinson, Genskow, Shaw, \& Shepard, 2012), in the context of real-estate markets (Benson, Hansen, \& Schwartz, 2000), or when performing decision-making on the basis of geoanalysis models (Yue, Wen, Chen, Lu, Hu, \& Zhang, 2015).

The interdisciplinary field that combines several viewpoints from economics and business sciences on the one hand, and those from spatial science - geography on the other hand, is a growing field of research, showing the needs of society to explore this interdisciplinary field. The systematic literature review of research results in this interdisciplinary field was conducted. The results presented in this paper show that the focus of the interdisciplinary interaction of these two fields, which we named "spationomy" (coined by combining the words "spatial" and "economy"), has been changing in the past.

Our paper arises from the importance of the ability to integrate business/ management knowledge and spatial sciences for students to become effective future employees, citizens, entrepreneurs, etc. Therefore, in the present research, students' behavioral intentions to use and integrate the interdisciplinary knowledge of economics/business sciences and of spatial science are analyzed. The data were obtained within the Erasmus+ Strategic Partnership Project called Spationomy, which started in 2016. Nowadays, the importance of the geospatial component inherent in most economic data is rapidly increasing, which is also reflected in the research results reported in the literature (Agliari, Commendatore, Foroni, \& Kubin, 2014; Brouder \& Eriksson, 2013; Hildreth \& Bailey, 2013; Rae \& Sener, 2016; Schulz \& Bailey, 2014; Terhorst \& Erkus-Oeztuerk, 2015), proving that the added value of bringing together geospatial aspects in economic data analysis is highly appreciated. The important aim of the Spationomy project is to improve students' interdisciplinary skills by interconnecting the fields of economy, business, management and business informatics on the one hand, and GIScience (including geoinformatics, geography, spatial information, remote sensing, etc.) on the other (Jürgens, Moos, \& Redecker, 2018).

The above mentioned behavioral intentions were studied with the research model based on the Theory of Reasoned Action (TRA) (Fishbein \& Ajzen, 1975) and the Technology Acceptance Model (TAM) (Davis, 1989; Davis, Bagozzi, \& Warshaw, 1989), which studied the users' acceptance of information systems. The reason for the adoption of TRA and TAM in our research is the fact that spationomy relies a great deal on technology and software support that enables retrieving information from the (big) databases and systems characteristic of spationomy. The use of different computer tools within the spationomy field - ERP (Enterprise resource planning) solutions, Power BI (Business Intelligence) reporting tools, SPSS (statistical software for social sciences), several GIS tools (ArcGIS for Desktop, ArcGIS Online and QGIS) - in which interdisciplinary knowledge and skills are embedded, supports the use of 
the TAM research model for our research. The integration and use of the spationomy interdisciplinary knowledge can also be considered as a use of certain information systems.

The main scientific contributions of this paper are: (i) confirmation, supported by the results of systematic review of scientific literature from this interdisciplinary field, that the spationomy topic is relevant and important in terms of the needs of the society, thus representing an important information for educational institutions in the process of management of their curricula, and (ii) confirmation that it is relevant to use the extended TAM to analyze and predict students' intentions to use and integrate the interdisciplinary knowledge of spationomy, thus enabling educational institutions to focus on relevant and important influential factors shaping these students' intentions.

\section{Literature Review}

In the first phase, a systematic literature review of this interdisciplinary field was conducted with the purpose to offer a clear picture of the "existence" of spationomy and its subfields, by conducting research of the most influential contributions in the field. The systematic search of the body of literature was conducted taking into account the journal articles written in English and listed in Scopus, since they are considered to be validated knowledge (Podsakoff, MacKenzie, Bachrach, \& Podsakoff, 2005). The obtained 776 articles were further analyzed to identify if they indeed addressed the interdisciplinary field of spationomy. This resulted in the final list of 724 papers. In the year 2000, a deep drop in the number of publications is evident, which could correspond with the widespread belief within the scientific community of these two fields (economy and geography) at that time, which was reflected in a provocative paper by Amin and Thrift (2000), as a call "for geographers to abandon all hopes of talking to and working with economists". However, after the year 2000, the number was increasing until 2010 and has been on the decrease afterwards.

A citation analysis was conducted by the Scopus citation tool to identify the most influential publications within this period (Gundolf \& Filser, 2013; Kraus, Filser, O'Dwyer, \& Shaw, 2014). The process resulted in a list of 57 documents. Categories that emerged from these most-cited publications, based on authors' keywords, were applied as the main topic areas addressed in articles. Additionally, all abstracts were carefully examined to justify the main topic areas. This resulted in the identification of four categories, presented in Table 1.

The results show that the focus of the "spationomy" research was changing in the past. In general, the research studies have moved from the less interrelated to the multirelated topics from both fields. The cluster that combines the keywords "residential locations", "housing", and "land market", is represented by the most cited paper from 1998, with 211 citations (André \& Platteau, 1998). Similarly, the cluster dealing 
with the keywords "population", "migration" and "employment", was predominant and characteristic for years before the turn of the century. On the other hand, the research that combines "spatial science", "geography" and "national economies", "firm performance" and "innovations" refers to the link between the two areas into an interdisciplinary research field and has been characteristic in the years after the turn of the century. The research work, which is most commonly quoted among all, dates back to the year just before the turn of the century (Feldman \& Audretsch, 1999). The fourth cluster refers to the "regional development" and "growth of cities", represented throughout the whole time period analysed.

The literature review reveals that the needs of society to explore and to understand the interrelations among geographical and economic aspects of individuals, organizations and the social environment are extensive and diversified, thus posing challenges to the educational institutions to equip graduates with the awareness of importance of spatial economy.

Table 1

Classification of the most cited papers

\begin{tabular}{|c|c|c|c|}
\hline Category & Paper & Journal & Citations \\
\hline \multirow{21}{*}{$\begin{array}{l}\text { Spatial science, } \\
\text { geography } \\
\text { and national } \\
\text { economies, } \\
\text { firm } \\
\text { performance } \\
\text { and } \\
\text { innovations }\end{array}$} & Feldman \& Audretsch (1999) & European Economic Review & 691 \\
\hline & Martin (1999) & Cambridge Journal of Economics & 371 \\
\hline & Boschma \& Lambooy (1999) & Journal of Evolutionary Economics & 290 \\
\hline & Hanson (2005) & Journal of International Economics & 243 \\
\hline & Breschi \& Lissoni (2009) & Journal of Economic Geography & 235 \\
\hline & Taylor (1996) & Environment and Planning A & 137 \\
\hline & Baldwin \& Okubo (2006) & Journal of Economic Geography & 119 \\
\hline & Oerlemans \& Meeus (2005) & Regional Studies & 103 \\
\hline & Truffer \& Coenen (2012) & Regional Studies & 100 \\
\hline & Olivier \& Slack (2006) & Environment and Planning A & 99 \\
\hline & McCann \& Mudambi (2004) & Growth and Change & 77 \\
\hline & Bruelhart (1998) & World Economy & 67 \\
\hline & Glaeser, Rosenthal, \& Strange (2010) & Journal of Urban Economics & 66 \\
\hline & McCann (2005) & Journal of Economic Geography & 66 \\
\hline & Boschma \& Frenken (2003) & Jahrbuch fur Regionalwissenschaft & 65 \\
\hline & Lakshmanan (2011) & Journal of Transport Geography & 59 \\
\hline & Lee (2002) & Progress in Human Geography & 55 \\
\hline & Masson \& Petiot (2009) & Technovation & 54 \\
\hline & Desrochers (2001) & Review of Austrian Economics & 54 \\
\hline & Fingleton (2003) & Intern. Regional Science Review & 51 \\
\hline & Pan, Kaski, \& Fortunato (2012) & Scientific Reports & 50 \\
\hline
\end{tabular}


Croatian Journal of Education, Vol.21; No.3/2019, pages: 861-892

\begin{tabular}{|c|c|c|c|}
\hline Category & Paper & Journal & Citations \\
\hline \multirow{15}{*}{$\begin{array}{l}\text { Population, } \\
\text { migration, } \\
\text { employment }\end{array}$} & Boyd (1989) & International Migration Review & 615 \\
\hline & Carlino \& Mills (1987) & Journal of Regional Science & 254 \\
\hline & Falkenmark \& Widstrand (1992) & Population Bulletin & 123 \\
\hline & Knapp \& Gravest (1989) & Journal of Regional Science & 119 \\
\hline & Small \& Song (1994) & Journal of Urban Economics & 105 \\
\hline & Williams, King, \& Warnes (1997) & Europ. Urban and Regional Studies & 91 \\
\hline & $\begin{array}{l}\text { Green, Hogarth, \& Shackleton } \\
\text { (1999) }\end{array}$ & Intern. Jour. of Popul. Geography & 85 \\
\hline & Alonso (1971) & Papers of the Reg. Sci. Association & 83 \\
\hline & Meyer \& Speare (1985) & Economic Geography & 67 \\
\hline & Moomaw \& Shatter (1996) & Journal of Urban Economics & 60 \\
\hline & Omran \& Roudi (1993) & Population Bulletin & 56 \\
\hline & Fan (1999) & International Migration Review & 55 \\
\hline & Desmet \& Fafchamps (2005) & Journal of Economic Geography & 54 \\
\hline & Woo \& Kwang (1984) & International Migration Review & 51 \\
\hline & Salt (1988) & Geoforum & 50 \\
\hline \multirow{10}{*}{$\begin{array}{l}\text { Residential } \\
\text { locations, } \\
\text { housing, land } \\
\text { market }\end{array}$} & André \& Platteau (1998) & Jour. of Econ. Behavior and Org. & 211 \\
\hline & Cervero \& Wu (1997) & Environment and Planning A & 154 \\
\hline & Myers \& Lee (1998) & International Migration Review & 82 \\
\hline & Levinson \& Kumar (1997) & Growth and Change & 81 \\
\hline & Linneman \& Graves (1983) & Journal of Urban Economics & 76 \\
\hline & Margo (1992) & Journal of Urban Economics & 59 \\
\hline & Rosenzweig \& Wolpin (1988) & Journal of Public Economics & 59 \\
\hline & Yang (1993) & International Migration Review & 58 \\
\hline & Ford (1990) & International Migration Review & 57 \\
\hline & Farley, Richards, \& Wurdock (1980) & Sociology of Education & 51 \\
\hline \multirow[t]{11}{*}{$\begin{array}{l}\text { Regional } \\
\text { development, } \\
\text { growth of cities }\end{array}$} & $\begin{array}{l}\text { Verburg, Soepboer, Veldkamp, } \\
\text { Limpiada, Espaldon, \& Mastura, } \\
(2002)\end{array}$ & Environmental Management & 545 \\
\hline & Lambooy \& Boschma (2001) & Annals of Regional Science & 93 \\
\hline & McCann (2008) & $\begin{array}{l}\text { Cambridge Journal of Regions, } \\
\text { Economy and Society }\end{array}$ & 88 \\
\hline & Griffith (1981) & Journal of Urban Economics & 78 \\
\hline & $\begin{array}{l}\text { Sparke, Sidaway, Bunnell, } \\
\text { \& Grundy-Warr (2004) }\end{array}$ & $\begin{array}{l}\text { Transactions of the Institute of } \\
\text { British Geographers }\end{array}$ & 73 \\
\hline & El-Shakhs (1972) & Journal of Developing Areas & 71 \\
\hline & $\begin{array}{l}\text { Richardson, Kaiser, Edwards-Jones, } \\
\text { \& Possingham (2006) }\end{array}$ & Conservation Biology & 70 \\
\hline & $\begin{array}{l}\text { Cumbers, MacKinnon, \& McMaster } \\
\text { (2003) }\end{array}$ & Europ. Urban and Regional Studies & 63 \\
\hline & Yeoh (1999) & Progress in Human Geography & 60 \\
\hline & Parr (1985) & Journal of Urban Economics & 60 \\
\hline & Plummer \& Sheppard (2006) & Journal of Economic Geography & 54 \\
\hline
\end{tabular}




\section{The Research Model}

In this research we utilized the modified version of TAM, as proposed by Davis, Bagozzi, \& Warshaw (1989). It postulated that the behavior (in our research, the use and integration of spationomy interdisciplinary knowledge) is determined by behavioral intentions to use it. Behavioral intentions are viewed as being jointly determined by the individual's attitudes towards usage and by the perceived usefulness, or in our research, the perceived usefulness of the spationomy interdisciplinary knowledge and attitudes towards its future use. Perceived ease of use - or in our research, the ease of use and integration of spationomy interdisciplinary knowledge - shapes the perceived usefulness, as well as the attitudes toward using it. In our research, we expanded the model by the external factors that describe personal-level characteristics (Chirawattanakij \& Ractham, 2016; Krueger, Norris, \& Carsrud, 1993; Linan \& Alain, 2015) that may be important when perceived ease of use and perceived usefulness of spationomy interdisciplinary knowledge are shaped by individuals.

A conceptual model of research is presented in Figure 1.

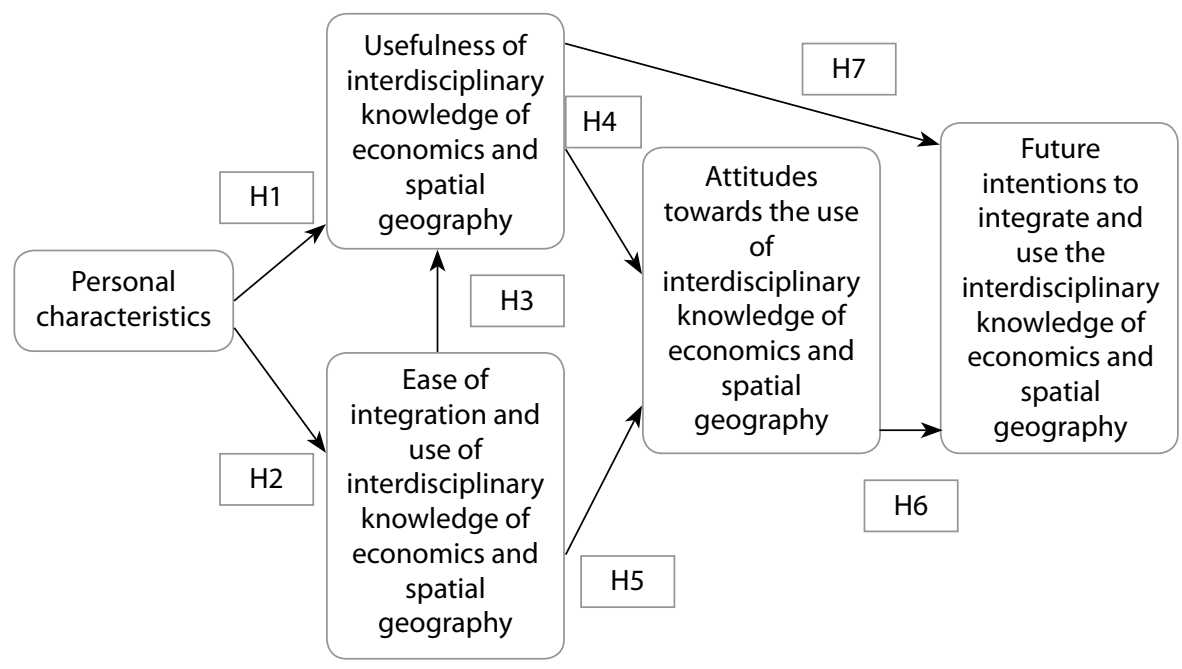

Figure 1. Conceptual model of research - interdisciplinary knowledge acceptance model

The following hypotheses were developed:

H1. Personal characteristics of students have an impact on the perceived usefulness of an interdisciplinary knowledge of spationomy.

H2. Personal characteristics of students have an impact on the perceived ease of integration and use of interdisciplinary knowledge of spationomy.

H3. The perceived ease of integration and use of interdisciplinary knowledge of spationomy has an impact on its perceived usefulness.

H4. The perceived usefulness of an interdisciplinary knowledge of spationomy has an impact on students' attitudes towards the use of this interdisciplinary knowledge. 
H5. The perceived ease of integration and use of interdisciplinary knowledge of spationomy has an impact on students' attitudes towards the use of this interdisciplinary knowledge.

H6. Students' attitudes towards the use of interdisciplinary knowledge of spationomy have an impact on students' future intentions to integrate and use this knowledge.

H7. The perceived usefulness of an interdisciplinary knowledge of spationomy has an impact on students' future intentions to integrate and use this knowledge.

\section{Methodology}

A sample of 99 students from partner institutions in the Spationomy project was formed: from two economics/business-oriented departments (Moravian University College Olomouc, the Czech Republic and the University of Maribor, Slovenia); a department from Palacký University Olomouc (the Czech Republic), oriented toward geoinformatics, and from Ruhr University Bochum (Germany), oriented towards geomatics. All students had completed the online questionnaire before the Spationomy project began with the purpose of gaining unbiased answers. The data were collected from February 27 to March 10, 2017.

A questionnaire with five measurement scales for measuring constructs of the model was employed. The items of constructs were made based on Davis's prior studies (Davis et al., 1989), with modifications to fit the specific context of the interdisciplinary knowledge, and based on the studies of Letchumanan \& Muniandy (2013), Park (2009), and Šebjan \& Tominc (2015). The measurement scale referring to personal characteristics was based on Ameen \& Loeffler-Cobia (2010); Arthur \& Yuet Wong (2000); Nikou \& Economides (2016); Pierce, Stacey, \& Barkatsas (2007); and Vos, van der Meijden, \& Denessen (2011). The research design consisted of the following constructs: Perceived usefulness of interdisciplinary knowledge (U), Perceived ease of integration and use of interdisciplinary knowledge (EU), Attitudes toward the use of interdisciplinary knowledge (AT), Intention to integrate and use interdisciplinary knowledge in the future (IN) and Personal characteristics construct as an external multidimensional construct.

All items were scored on a 7-point Likert scale ranging from 1 (strongly disagree) to 7 (strongly agree). The questionnaire was tested in a pilot study with a group of 10 students, as well as with three academics from the human resource management and psychology fields to improve the structure and wording.

In the second step, first the Confirmatory Factor Analysis (CFA) within Structural Equation Modelling (SEM) was used. For factor loadings of indicators, criteria higher than the value of 0.7 were used (Henseler, Ringle, \& Sarstedt, 2015). The model measurement fit was assessed by composite reliabilities for constructs where the criteria equal to or greater than 0.6 were used (Chin, 1998); by Cronbach's alphas, that also describe convergent validity and hence reliability equal to or greater than 0.6 (Garson, 2016); and average variance extracted (AVE) to test both convergent and divergent validity that is greater than 0.5 (Chin, 1998). AVEs were also used to 
establish discriminant validities by the Fornell-Larcker criterion, with the square root of AVE for any latent variable being higher than its correlation with any other latent variable (Garson, 2016). Discriminant validities were also assessed by the HeterotraitMonotrait Ratio (HTMT) (Henseler, Ringle, \& Sarstedt, 2015) with HTMT ratio being below 1 , while a more stringent cut-off of 0.85 was used in the past research (Kline, 2011). A model fit was assessed by the standardized root mean square residual (SRMR). A model has a good fit when SRMR is less than 0.10 (Garson, 2016), while some use a more rigorous cut-off of less than 0.08 (Hu \& Bentler, 1998). Structural path coefficients (loadings - standardized regression coefficients) were analyzed using significance level at $0.05 . R^{2}$ values and Adjusted $R^{2}$ were used to measure the overall effect size for the structural equation model, with the results above the cut-offs of $0.67,0.33$ and 0.19 being substantial, moderate and weak, respectively (Chin, 1998).

Statistical Package for the Social Sciences (SPSS) and SmartPLS software were used.

\section{Results}

The results confirmed the described one-dimensional structure of constructs $U$, EU, AT and IN, while the Personal characteristics of students were included by the three two-dimensional, second-order constructs: Propulsiveness at studies (consisting of Ambitiousness and Innovativeness), Involvement and persistence within studies (consisting of Personal motivation and Behavioral engagement), Orientations and attitudes towards studies (consisting of Self-confidence at studies and analytical thinking, and Research orientation within studies).

Table 2 shows the results of the model measurement fit, indicating that the composite reliability is adequate. The Fornell-Larcker criterion and a variables' correlation matrix is presented in Table 3, confirming the discriminant validity. The Heterotrait-Monotrait Ratio results in Table 4 confirm the discriminant validity. The standardized root mean square residual SRMR equals 0.096 , which is acceptable for the preliminary model.

Table 2

Composite reliability, Cronbach's alphas, and Average variance extracted

\begin{tabular}{lccc}
\hline & $\begin{array}{c}\text { Composite } \\
\text { reliability }\end{array}$ & $\begin{array}{c}\text { Cronbach } \\
\text { alpha }\end{array}$ & AVE \\
\hline Ambitiousness & 0.914 & 0.859 & 0.780 \\
Innovativeness & 0.917 & 0.864 & 0.786 \\
Personal motivation & 0.836 & 0.707 & 0.631 \\
Behavioural engagement & 0.882 & 0.822 & 0.652 \\
Self-confidence and analytical thinking & 0.929 & 0.913 & 0.621 \\
Research orientation & 0.881 & 0.820 & 0.651 \\
Usefulness & 0.904 & 0.872 & 0.612 \\
Ease of use & 0.922 & 0.887 & 0.747 \\
Attitudes towards the use & 0.950 & 0.930 & 0.827 \\
Intentions of future use & 0.915 & 0.864 & 0.783 \\
\hline
\end{tabular}


The examination of the endogenous constructs' predictive power (see Table 5) shows that Intention of future use, which is the primary outcome measure of the model, has a close to substantial $R^{2}$ value 0.580 . Prediction of Attitude toward the use is also high, with an $R^{2}$ value of 0.715 , whereas the prediction of Perceived ease of use is weak $\left(R^{2}=0.157\right)$.

Statistically significant relationships among the constructs were tested for hypotheses $\mathrm{H} 1$ - H7. The $t$-statistics values were obtained using bootstrapping with the resampling method. In Table 6, the significant path coefficients are presented (original sample and sample mean), along with standard deviations and $t$-statistics.

Table 3

The Fornell-Larcker criterion and the variables' correlation matrix

\begin{tabular}{|c|c|c|c|c|c|c|c|c|c|c|}
\hline & 1 & 2 & 3 & 4 & 5 & 6 & 7 & 8 & 9 & 10 \\
\hline 1. Ambitiousness & 0.883 & & & & & & & & & \\
\hline 2. Innovativeness & 0.583 & 0.887 & & & & & & & & \\
\hline 3. Personal motivation & 0.442 & 0.450 & 0.794 & & & & & & & \\
\hline 4. Behavioural engagement & 0.530 & 0.401 & 0.543 & 0.808 & & & & & & \\
\hline $\begin{array}{l}\text { 5. Self-confidence and } \\
\text { analytical thinking }\end{array}$ & 0.657 & 0.640 & 0.653 & 0.699 & 0.788 & & & & & \\
\hline 6. Research orientation & 0.445 & 0.479 & 0.632 & 0.445 & 0.592 & 0.807 & & & & \\
\hline 7. Usefulness & 0.450 & 0.407 & 0.455 & 0.372 & 0.412 & 0.510 & 0.782 & & & \\
\hline 8. Ease of use & 0.230 & 0.374 & 0.223 & 0.277 & 0.381 & 0.310 & 0.573 & 0.864 & & \\
\hline 9. Attitudes towards the use & 0.346 & 0.347 & 0.413 & 0.431 & 0.427 & 0.463 & 0.802 & 0.679 & 0.909 & \\
\hline 10. Intentions of future use & 0.378 & 0.342 & 0.431 & 0.343 & 0.422 & 0.419 & 0.553 & 0.711 & 0.733 & 0.885 \\
\hline
\end{tabular}

Table 4

The Heterotrait-Monotrait Ratio

\begin{tabular}{|c|c|c|c|c|c|c|c|c|c|}
\hline & 1 & 2 & 3 & 4 & 5 & 6 & 7 & 8 & 9 \\
\hline \multicolumn{10}{|l|}{ 1. Ambitiousness } \\
\hline 2. Innovativeness & 0.673 & & & & & & & & \\
\hline 3. Personal motivation & 0.556 & 0.575 & & & & & & & \\
\hline 4. Behavioural engagement & 0.626 & 0.460 & 0.697 & & & & & & \\
\hline $\begin{array}{l}\text { 5. Self-confidence and } \\
\text { analytical thinking }\end{array}$ & 0.739 & 0.720 & 0.809 & 0.808 & & & & & \\
\hline 6. Research orientation & 0.526 & 0.566 & 0.835 & 0.526 & 0.676 & & & & \\
\hline 7. Usefulness & 0.512 & 0.472 & 0.577 & 0.436 & 0.461 & 0.601 & & & \\
\hline 8. Ease of use & 0.273 & 0.426 & 0.282 & 0.313 & 0.422 & 0.358 & 0.650 & & \\
\hline 9. Attitudes towards the use & 0.385 & 0.388 & 0.510 & 0.488 & 0.465 & 0.524 & 0.891 & 0.741 & \\
\hline 10. Intentions of future use & 0.436 & 0.384 & 0.548 & 0.399 & 0.475 & 0.483 & 0.832 & 0.622 & 0.775 \\
\hline
\end{tabular}


Table 5

Goodness of fit for the structural model

\begin{tabular}{lcc}
\hline & R square & Adjusted R square \\
Ambitiousness & 0.792 & 0.790 \\
Innovativeness & 0.791 & 0.789 \\
Personal motivation & 0.695 & 0.692 \\
Behavioural engagement & 0.839 & 0.838 \\
Self-confidence and analytical thinking & 0.913 & 0.912 \\
Research orientation & 0.646 & 0.642 \\
Usefulness & 0.452 & 0.435 \\
Ease of use & 0.157 & 0.148 \\
Attitudes towards the use & 0.715 & 0.709 \\
Intentions of future use & 0.580 & 0.571 \\
\hline
\end{tabular}

Table 6

Path coefficients

\begin{tabular}{lccccc}
\hline Relationship & $\begin{array}{c}\text { Coefficient } \\
\text {-Original sample }\end{array}$ & $\begin{array}{c}\text { Coefficient - } \\
\text { Sample mean }\end{array}$ & $\begin{array}{c}\text { Standard } \\
\text { error }\end{array}$ & t-statistics & $p$ values \\
\hline $\begin{array}{l}\text { Propulsiveness } \rightarrow \text { Usefulness } \\
\text { Involvement \& persistence } \rightarrow\end{array}$ & 0.207 & 0.205 & 0.102 & 2.040 & 0.042 \\
Usefulness & 0.216 & 0.217 & 0.099 & 2.183 & 0.030 \\
Orientation and attitudes $\rightarrow$ Ease of use & 0.396 & 0.395 & 0.095 & 4.185 & 0.000 \\
Ease of use $\rightarrow$ Usefulness & 0.440 & 0.445 & 0.087 & 5.035 & 0.000 \\
Ease of use $\rightarrow$ Attitudes towards use & 0.327 & 0.328 & 0.060 & 5.487 & 0.000 \\
Usefulness $\rightarrow$ Attitudes towards use & 0.615 & 0.613 & 0.065 & 9.526 & 0.000 \\
Usefulness $\rightarrow$ Intentions & 0.454 & 0.454 & 0.113 & 4.035 & 0.000 \\
Attitudes towards use $\rightarrow$ Intentions & 0.347 & 0.339 & 0.111 & 3.117 & 0.002 \\
\hline
\end{tabular}

Results show that the Propulsiveness of students, as well as students' Involvement and persistence, both have a significant and positive effect on the perceived Usefulness of integration and use of the spationomy interdisciplinary knowledge $(\beta=0.207$ and $\beta=0.216$ respectively). On the other hand, the third construct of personal characteristics, Orientations and attitudes towards studies, has a significant positive effect on the students' perceived Ease of use $(\beta=0.396)$. Therefore, hypotheses H1 and $\mathrm{H} 2$ can be partly confirmed.

The hypothesized direct and indirect effects among constructs in the model are significant and all positive. The perceived Ease of integration and use of spationomy interdisciplinary knowledge has a statistically significant effect on the students' perceived Usefulness $(\beta=0.440)$, as well as on students' Attitudes towards the use of spationomy interdisciplinary knowledge $(\beta=0.327)$. Therefore, hypotheses $\mathrm{H} 3$ and $\mathrm{H} 5$ are confirmed.

Results also confirm hypotheses $\mathrm{H} 4, \mathrm{H} 6$ and $\mathrm{H} 7$. The students' perceived Usefulness of spationomy interdisciplinary knowledge has a direct effect on students' Intentions 
to use this interdisciplinary knowledge in the future $(\beta=0.454)$, thus confirming H7. However, the perceived Usefulness also has an indirect effect on students' Intentions to use the spationomy knowledge. Namely, the perceived Usefulness has a significant positive effect on the students' Attitudes towards the use of spationomial interdisciplinary knowledge $(\beta=0.615)$, thus confirming $\mathrm{H} 4$, and Attitudes have a direct effect on students' Intentions to use the spationomial knowledge in the future $(\beta=0.347)$. This also confirms H6.

\section{Discussion and Conclusions}

The research proved the interdisciplinary nature of spatial sciences (and geography which is spatial in its nature) that frequently deal with issues related to other disciplines. Economic geography, as a subfield of human geography, with its tradition going back to the end of the nineteenth century, remains one of the core subfields within Anglo-American geography (Barnes, 2004), and a significant subfield in European geographical context as well. Barnes (2004) also states that economic geography is being "muddy and indistinct" when talking about its boundaries with other disciplines. Therefore, the authors of this paper think that "pure" geographers (and spatial scientists) and economists can and should work together on common geographical or economic interests, including the education of young people (students) in these fields. Moreover, member states of the EU are strongly encouraged by EU research and education mechanisms to support interdisciplinary research in their development programs, including research and education (e.g., European Commission, 2015). The presented paper proves that the interdisciplinary element is crucial in the sense of previous statements, and more importantly, it is perceived positively by the young generation of both geographers and economists. This is reflected in students' attitudes towards the use and integration of this interdisciplinary knowledge, which shape their intentions to integrate and use the interdisciplinary knowledge of geography and spatial science not only in economy but in general. Unique experiences and opportunities gained during the Spationomy project can contribute to building geographical knowledge of the young generation of economists, and further develop the competences of their fellow geographers (and spatial scientists).

At the country level, valid for all participating states, the implication of this research can be summarized as: 1) increased subject awareness of spatial economy (economic geography) in higher education; 2) significant usability proof of interdisciplinary approach in the sense that students are open to cooperate on cross-disciplinary topics; and 3) the authors believe that both academics and students gained momentum to generate new ideas and knowledge, which underlines the interdisciplinary nature of geography. Our research also confirms research results in the literature that were targeted at the analysis of sustainable development, and which emphasized the importance of combining economic, social, spatial and wider environmental viewpoints (Vintar Mally, 2018) since sustainable development is also challenged by 
the effects of modern human economic activity on the spatial elements (Đukičin, Đorđević, \& Milanković 2014). These studies also stress that, aside from locating and mapping geospatial characteristics, geospatial data must be added to other socioeconomic and demographic data so as to facilitate informed decision-making among policy makers.

Our study is also facing limitations, that, at the same time, represent possibilities for further research, especially regarding the implications for educators. Since students nowadays need to think beyond boundaries of their narrow study discipline, and have to gain competences to think and act across disciplines, the important question is how to bring the effective interdisciplinary reasoning and communication training into the education systems. The Erasmus+ Strategic Partnership Project Spationomy, within which this research was conducted, offers a unique opportunity to develop the tailor made approaches to the teaching and learning approaches within the interdisciplinary field of economic/business studies and spatial science - geography. The future years of the project with the enlarged number of students participating will enable re-testing to establish if important differences regarding the perceived usefulness, ease of use and attitudes among students, before and after participating in the Spationomy project, still exist. This will enable us to test the appropriateness of learning and teaching approaches (based on blended learning and focused on simulation games). Testing the difference among students of both fields - economics/business and spatial science - geography, is important task for the future years as well. If these differences exist, the diversified approach to the education may be an important influencing factor for successful implementation of cross-disciplinary approaches.

On the other hand, the educators may also face obstacles and barriers for integrating economics and business sciences with spatial science - geography. Robinson, Genskow, Shaw, and Shepard (2012) utilized the theory of planned behavior to determine and describe the factors that predict practitioners' intents to integrate social science into natural resource management work. Although the practitioners' daily work and work activities may be different, teachers/educators may face similar obstacles when the economic/business viewpoints and spatial science - geography are to be integrated within the studies. Similar to the research results of Robinson, Genskow, Shaw, and Shepard (2012), teachers' decisions to incorporate these interdisciplinary aspects may be influenced by their confidence in their own capability to incorporate these fields and by their beliefs that outcomes of this integration would represent valuable and beneficial learning outcomes. The future years of the Spationomy project will offer the opportunity to analyze these aspects as well.

To conclude, the research results confirm the importance of integration of economics/business and spatial sciences' knowledge, for graduates who nowadays have to think and act interdisciplinary. As presented in the paper, the results of the study have important implications for higher education institutions, reforming and updating their study programs, as well as for educators in the field of spatial and economic/business sciences, in research and in education. 


\section{Acknowledgement}

This paper is supported by the project no. 2016-1-CZ01-KA203-024040 Spatial exploration of economic data: methods of interdisciplinary analytics (Spationomy) funded by the European Union within the Erasmus+ programme.

\section{References}

Agliari, A., Commendatore, P., Foroni, I., \& Kubin, I. (2014). Expectations and industry location: A discrete time dynamical analysis. Decisions in Economics and Finance, 37(1), 3-26. https://doi.org/10.1007/s10203-012-0139-1

Alonso, W. (1971). The economics of urban size. Papers of the Regional Science Association. 26(1), 66-83. https://doi.org/10.1007/BF01908693

Ameen, C. A., \& Loeffler-Cobia, J. (2010). Evidence-based practices skills assessment for criminal justice organizations. Washington: National Institute of Corrections.

Amin, A., \& Thrift, N. (2000), What kind of economic theory for what kind of economic geography?. Antipode, 32(1), 4-9. https://doi.org/10.1111/1467-8330.00117

André, C., \& Platteau, J. (1998). Land relations under unbearable stress: Rwanda caught in the Malthusian trap. Journal of Economic Behavior and Organization, 34(1), 1-47. https:// doi.org/10.1016/S0167-2681(97)00045-0

Arthur, D., \& Yuet Wong, F. K. (2000). The effects of the 'learning by proposing to do' approach on Hong Kong nursing students' research orientation, attitude toward research, knowledge and research skill. Nurse Education Today, 20, 662-671. https://doi.org/10.1054/ nedt.2000.0486

Baldwin, R. E., \& Okubo, T. (2006). Heterogeneous firms, agglomeration and economic geography: Spatial selection and sorting. Journal of Economic Geography, 6(3), 323-346. https://doi.org/10.1093/jeg/lbi020

Barnes, T. (2004). The rise (and decline) of American regional science: Lessons for the new economic geography. Journal of Economic Geography, 4, 107-129. https://doi.org/10.1093/ jeg/4.2.107

Benson, E. D., Hansen J. L., \& Schwartz, A. L. Jr. (2000). Water views and residential property values. The Appraisal Journal, 3(48), 260-271.

Boschma, R. A., \& Frenken, K. (2003). Evolutionary economics and industry location. Jahrbuch Fur Regionalwissenschaft, 23(2), 183-200.

Boschma, R. A., \& Lambooy, J. G. (1999). Evolutionary economics and economic geography. Journal of Evolutionary Economics, 9(4), 411-429. https://doi.org/10.1007/s001910050089

Boyd, M. (1989). Family and personal networks in international migration: Recent developments and new agendas. International Migration Review, 23(3), 638-670. https:// doi.org/10.2307/2546433

Breschi, S., \& Lissoni, F. (2009). Mobility of skilled workers and co-invention networks: An anatomy of localized knowledge flows. Journal of Economic Geography, 9(4), 439-468. https://doi.org/10.1093/jeg/lbp008 
Tominc, Paszto, Bobek and Sternad Zabukovšek: Integration and Use of the Interdisciplinary Knowledge ...

Brouder, P., \& Eriksson, R. H. (2013). Staying power: what influences micro-firm survival in tourism? Tourism Geographies, 15(1), 125-164. http://dx.doi.org/10.1080/14616688.2 $\underline{011.647326}$

Carlino, G. A., \& Mills, E. S. (1987). The determinants of county growth. Journal of Regional Science, 27(1), 39-54. http://dx.doi.org/10.1111/j.1467-9787.1987.tb01143.x

Cervero, R., \& Wu, K. (1997). Polycentrism, commuting, and residential location in the San Francisco Bay area. Environment and Planning, 29(5), 865-886. https://doi.org/10.1068/ $\underline{\mathrm{a} 290865}$

Chin, W.W. (1998). The partial least squares approach for structural equation modeling. In G. A. Macoulides (Ed.), Modern Methods for business research (pp. 295-336). Mahwah, Nj: Lawrence Erlbaum Associates.

Chirawattanakij, S., \& Ractham, V. V. (2015). Knowledge adoption: The influential factors in the process. Business Information Review, 32(3), 158-167. https://doi.org/10.1177/02663821

Cumbers, A., MacKinnon, D., \& McMaster, R. (2003). Institutions, power and space: Assessing the limits to institutionalism in economic geography. European Urban and Regional Studies, 10(4), 325-342. https://doi.org/10.1177/09697764030104003

Davis, F. D. (1989). Perceived usefulness, perceived ease of use, and user acceptance of information technology. MIS Quarterly, 13(3), 319-340. https://doi.org/10.2307/249008

Davis, F. D., Bagozzi, P. R., \& Warshaw, P. R. (1989). User acceptance of computer technology: A comparison of two theoretical models. Management Science, 35(8), 319-340. https://doi. org/10.1287/mnsc.35.8.982

Desmet, K., \& Fafchamps, M. (2005). Changes in the spatial concentration of employment across US counties: A sectoral analysis 1972-2000. Journal of Economic Geography, 5(3), 261-284. https://doi.org/10.1093/jnlecg/lbh046

Desrochers, P. (2001). Geographical proximity and the transmission of tacit knowledge. Review of Austrian Economics, 14(1), 25-46. https://doi.org/10.1023/A:1007803520748

El-Shakhs, S. (1972). Development, primacy, and systems of cities. Journal of Developing Areas, 7(1), 11-35.

Đukičin, S., Đorđević, J., \& Milanković, J. (2014). Spatial and social changes caused by the continuous exploitation of lignite in the Kolubara lignite basin, Serbia. Acta geographica Slovenica, 54(1), 41-49. http://dx.doi.org/10.3986/AGS54102

European Commission (2015). Quests for interdisciplinarity: A challenge for the ERA and HORIZON 2020. Policy Brief by the Research, Innovation, and Science Policy Experts. Luxemburg. https://doi.org/10.2777/499518, ISBN 978-92-79-50188-3

Falkenmark, M., \& Widstrand, C. (1992). Population and water resources: A delicate balance. Population Bulletin, 47(3), 1-36.

Fan, C. C. (1999). Migration in a socialist transitional economy: Heterogeneity, socioeconomic and spatial characteristics of migrants in China and Guangdong province. International Migration Review, 33(4), 954-987. https://doi.org/10.1177/019791839903300406

Farley, R., Richards, T., \& Wurdock, C. (1980). School desegregation and white flight: An investigation of competing models and their discrepant findings. Sociology of Education, 53(3), 123-139. https://doi.org/10.2307/2112408 
Feldman, M. P., \& Audretsch, D. B. (1999). Innovation in cities: Science-based diversity, specialization, and localized competition. European Economic Review, 43(2), 409-429. https://doi.org/10.1016/S0014-2921(98)00047-6

Fingleton, B. (2003). Externalities, economic geography, and spatial econometrics: Conceptual and modeling developments. International Regional Science Review, 26(2), 197-207. https://doi.org/10.1177/0160017602250976

Fishbein, M., \& Ajzen, I. (1975). Belief, attitude, intention, and behaviour: An introduction to the theory and research. Reading, Ma: Addison-Wesley.

Ford, K. (1990). Duration of residence in the United States and the fertility of US immigrants. International Migration Review, 24(1), 34-68. https://doi.org/10.2307/2546671

Garson, G. D. (2016). Partial least squares: regression and structural equation models. Asheboro: Statistical Publishing Associates.

Glaeser, E. L., Rosenthal, S. S., \& Strange, W. C. (2010). Urban economics and entrepreneurship. Journal of Urban Economics, 67(1), 1-14. https://doi.org/10.1016/j.jue.2009.10.005

Green, A. E., Hogarth, T., \& Shackleton, R. E. (1999). Longer distance commuting as a substitute for migration in Britain: A review of trends, issues, and implications. International Journal of Population Geography, 5(1), 49-67. https://doi.org/10.1002/ (SICI)1099-1220(199901/02)5:1<49::AID-IJPG124>3.0.CO;2-O

Griffith, D. A. (1981). Modelling urban population density in a multi-centered city. Journal of Urban Economics, 9(3), 298-310. https://doi.org/10.1016/0094-1190(81)90029-2

Gundolf, K., \& Filser, M. (2013). Management research and religion: a citation analysis. Journal of Business Ethics, 112(1), 177-185. https://doi.org/10.1007\%2Fs10551-012-12

Hanson, G. H. (2005). Market potential, increasing returns and geographic concentration. Journal of International Economics, 67(1), 1-24. https://doi.org/10.1016/j.jinteco.2004.09.008

Henseler, J., Ringle, C. M., \& Sarstedt, M. (2015). A new criterion for assessing discriminants validity in variance-based structural equation modelling. Journal of the Academy of Marketing Science, 43(1), 115-135. https://doi.org/10.1007/s11747-014-0403

Hildreth, P., \& Bailey, D. (2013). The economics behind the move to 'localism' in England. Cambridge Journal of Regions, Economy, and Society, 6(2), 233-249. https://doi.org/10.1093/ cjres/rst004

Hu, L. T., \& Bentler, P. M. (1998). Fit indices in covariance structure modeling: Sensitivity to underparameterized model misspecification. Psychological Methods, 3(4), 233-249. http:// dx.doi.org/10.1037/1082-989X.3.4.424

Jürgens, C., Moos, N., \& Redecker, A. P. (2018). Spationomy: Spatial Exploration of Economic Data - an Interdisciplinary Geomatics Project. Kartographische Nachrichten, 68(2), 66-71.

Kline, R. B. (2011). Principles and practice of structural equation modeling. New York: Guilford Press.

Knapp, T. A., \& Gravest, P. E. (1989). On the role of amenities in models of migration and regional development. Journal of Regional Science, 29(1), 71-87. http://doi. org/10.1111/j.1467-9787.1989.tb01223.x

Kraus, S., Filser, M., O’Dwyer, M., \& Shaw, E. (2014). Social entrepreneurship: an exploratory citation analysis. Review of Managerial Science, 8(2), 275-292. http://doi.org/10.1007/ $\underline{\text { s11846-013-0104-6 }}$ 
Tominc, Paszto, Bobek and Sternad Zabukovšek: Integration and Use of the Interdisciplinary Knowledge ...

Krueger, F., Norris, A., \& Carsrud, I. (1993). Entrepreneurial intentions: Applying the theory of planned behaviour. Entrepreneurship and Regional Development, 5(4), 315-330. http:// doi.org/10.1080/08985629300000020

Lakshmanan, T. R. (2011). The broader economic consequences of transport infrastructure investments. Journal of Transport Geography, 19(1), 1-12. https://doi.org/10.1016/j. jtrangeo.2010.01.001

Lambooy, J. G., \& Boschma, R.A. (2001). Evolutionary economics and regional policy. Annals of Regional Science, 35(1), 113-131. https://doi.org/10.1007/s001680000033

Lee, R. (2002). 'Nice maps, shame about the theory'? Thinking geographically about the economic. Progress in Human Geography, 26(3), 333-355. https://doi. org/10.1191/0309132502ph373ra

Letchumanan, M., \& Muniandy, B. (2013). Migrating to e-book: a study on perceived usefulness and ease of use. Library Hi Tech News, 30(7), 10-15. https://doi.org/10.1108/ LHTN-05-2013-0028

Levinson, D. M., \& Kumar, A. (1997). Density and the journey to work. Growth and Change, 28(2), 147-172. https://doi.org/10.1111/j.1468-2257.1997.tb00768.x

Linan, F., \& Alain, F. (2015). A systematic literature review on EI: citation, thematic analyses and research agenda. International Entrepreneurship and Management Journal, 11(4), 907 933. https://doi.org/10.1007/s11365-015-0356-5

Linneman, P., \& Graves, P. E. (1983). Migration and job change: A multinomial logit approach. Journal of Urban Economics, 14(3), 907-933. https://doi.org/10.1016/0094$\underline{1190(83) 90009-8}$

Margo, R. A. (1992). Explaining the postwar suburbanization of population in the United States: The role of income. Journal of Urban Economics, 31(3), 301-310. https://doi. org/10.1016/0094-1190(92)90058-S

Martin, R. (1999). The new 'geographical turn' in economics: Some critical reflections. Cambridge Journal of Economics, 23(1), 65-91. https://doi.org/10.1093/cje/23.1.65

Masson, S., \& Petiot, R. (2009). Can the high-speed rail reinforce tourism attractiveness? The case of the high-speed rail between Perpignan (France) and Barcelona (Spain). Technovation, 29(9), 611-617. https://doi.org/10.1016/j.technovation.2009.05.013

McCann, P. (2005). Transport costs and new economic geography. Journal of Economic Geography, 5(3), 305-318. https://doi.org/10.1093/jnlecg/lbh050

McCann, P. (2008). Globalization and economic geography: the world is curved, not flat. Cambridge Journal of Regions, Economy, and Society, 1(3), 351-370. https://doi.org/10.1093/ cjres/rsn002

McCann, P., \& Mudambi, R. (2004). The location behavior of the multinational enterprise: Some analytical issues. Growth and Change, 35(4), 491-524. https://doi.org/10.1111/j.14682257.2004.00259.x

Meyer, J. W., \& Speare, A. (1985). Distinctively elderly mobility: Types and determinants. Economic Geography, 61(1), 79-88. https://doi.org/10.2307/143676

Moomaw, R. L., \& Shatter, A. M. (1996). Urbanization and economic development: A bias toward large cities? Journal of Urban Economics, 40(1), 13-37. https://doi.org/10.1006/ juec.1996.0021 
Myers, D., \& Lee, S. W. (1998). Immigrant trajectories into homeownership: A temporal analysis of residential assimilation. International Migration Review, 32(3), 593-625. https:// doi.org/10.2307/2547765

Nikou, S. A., \& Economides, A. A. (2016). The impact of paper-based, computer-based and mobile-based self-assessment on students' science motivation and achievement. Computers in Human Behavior, 55, 1241-1248. https://doi.org/10.1016/j.chb.2015.09.025

Oerlemans, L. A. G., \& Meeus, M. T. H. (2005). Do organizational and spatial proximity impact on firm performance?. Regional Studies, 39(1), 89-104. https://doi. org/10.1080/0034340052000320896

Olivier, D., \& Slack, B. (2006). Rethinking the port. Environment and Planning A, 38(8), 14091427. https://doi.org/10.1068/a37421

Omran, A. R., \& Roudi, F. (1993). The middle east population puzzle. Population Bulletin, 48(1), 1-40.

Pan, R. K., Kaski, K., \& Fortunato, S. (2012). World citation and collaboration networks: Uncovering the role of geography in science. Scientific Reports, 2, 1-7. https://doi. org/10.1038/srep00902

Park, S. Y. (2009). An analysis of the technology acceptance model in understanding university students' behavioral intention to use e-learning. Educational Technology \& Society, 12(3), 150-162.

Parr, J. B. (1985). A note on the size distribution of cities over time. Journal of Urban Economics, 18(2), 199-212. https://doi.org/10.1016/0094-1190(85)90017-8

Pierce, R., Stacey, K., \& Barkatsas, A. (2007). A scale for monitoring students' attitudes to learning mathematics with technology. Computers \& Education, 48, 258-300. https://doi. org/10.1016/j.compedu.2005.01.006

Podsakoff, P. M., MacKenzie, S. B., Bachrach, D. G., \& Podsakoff, N. P. (2005). The influence of management journals in the 1980s and 1990s. Strategic Management Journal, 26(3), 473-488.

Plummer, P., \& Sheppard, E. (2006). Geography matters: Agency, structures, and dynamics at the intersection of economics and geography. Journal of Economic Geography, 6(5), 619637. https://doi.org/10.1093/jeg/lbl005

Rae, A., \& Sener, E. (2016). How website users segment a city: The geography of housing search in London. Cities, 52, 140-147. https://doi.org/10.1016/j.cities.2015.12.002

Richardson, E. A., Kaiser, M. J., Edwards-Jones, G., \& Possingham, H. P. (2006). Sensitivity of marine-reserve design to the spatial resolution of socioeconomic data. Conservation Biology, 20(4), 1191-1202. https://doi.org/10.1111/j.1523-1739.2006.00426.x

Robinson, P., Genskow, K., Shaw, B., \& Shepard, R. (2012). Barriers and opportunities for integrating social science into natural resource management: Lessons from national estuarine research reserves. Environmental Management, 50(6), 998-1011. https://doi. org/10.1007/s00267-012-9930-6

Rodriguez, M., \& Sirmans, C. F. (1994). Quantifying the value of a view in single family housing markets. The Appraisal Journal, 10, 600-603.

Rosenzweig, M. R., \& Wolpin, K. I. (1988). Migration selectivity and the effects of public programs. Journal of Public Economics, 37(3), 265-289. https://doi.org/10.1016/0047$\underline{2727(88) 90042-4}$ 
Tominc, Paszto, Bobek and Sternad Zabukovšek: Integration and Use of the Interdisciplinary Knowledge ...

Salt, J. (1988). Highly-skilled international migrants, careers and internal labour markets. Geoforum, 19(4), 387-399. https://doi.org/10.1068/a3541

Schulz, C., \& Bailey, I. (2014). The green economy and post-growth regimes: Opportunities and challenges for economic geography. Geografiska Annaler, Series B: Human Geography, 96(3), 277-291. https://doi.org/10.1111/geob.12051

Shen, J., Sung, S., \& Zhang, D. (2015). Toward an analytic framework of interdisciplinary reasoning and communication (IRC) processes in science. International Journal of Science Education, 37(17), 2809-2835. http://dx.doi.org/10.1080/09500693.2015.1106026

Small, K. A., \& Song, S. (1994). Population and employment densities: Structure and change. Journal of Urban Economics, 36(3), 292-313. https://doi.org/10.1006/juec.1994.1037

Sparke, M., Sidaway, J. D., Bunnell, T., \& Grundy-Warr, C. (2004). Triangulating the borderless world: Geographies of power in the Indonesia-Malaysia-Singapore growth triangle. Transactions of the Institute of British Geographers, 29(4), 485-498. https://doi.org/10.1111/ j.0020-2754.2004.00143.x

Šebjan, U., \& Tominc, P. (2015). Impact of support of teacher and compatibility with needs of study on usefulness of SPSS by students. Computers in Human Behavior, 53, 354-365. https://doi.org/10.1016/j.chb.2015.07.022

Taylor, P. J. (1996). Embedded statism and the social sciences: Opening up to new spaces. Environment and Planning A, 28(11), 1917-1928. https://doi.org/10.1068/a32153

Terhorst, P., \& Erkuş-Öztürk, H. (2015). Urban tourism and spatial segmentation in the field of restaurants: The case of Amsterdam. International Journal of Culture, Tourism, and Hospitality Research, 9(2), 85-102. https://doi.org/10.1108/IJCTHR-09-2014-0074

Truffer, B., \& Coenen, L. (2012). Environmental innovation and sustainability transitions in regional studies. Regional Studies, 46(1), 1-21. https://doi.org/10.1080/00343404.2012 .646164

Verburg, P. H., Soepboer, W., Veldkamp, A., Limpiada, R., Espaldon, V., \& Mastura, S. S. A. (2002). Modeling the spatial dynamics of regional land use: The CLUE-S model. Environmental Management, 30(3), 391-405. https://doi.org/10.1007/s00267-002-2630-x

Vintar Mally, K. (2018). Regional differences in Slovenia from the viewpoint of achieving Europe's sustainable development. Acta geographica Slovenica, 58(2), 31-46. https://doi. org/10.3986/AGS.3309

Vos, N., van der Meijden, H., \& Denessen, E. (2011). Effects of constructing versus playing an educational game on student motivation and deep learning strategy use. Computers \& Education, 56, 127-137. https://doi.org/10.1016/j.compedu.2010.08.013

Williams, A. M., King, R., \& Warnes, T. (1997). A place in the sun: International retirement migration from northern to southern Europe. European Urban and Regional Studies, 4(2), 115-134. https://doi.org/10.1177/096977649700400202

Woo, M. H., \& Kwang, C. K. (1984). Adhesive sociocultural adaptation of Korean immigrants in the US: An alternative strategy of minority adaptation. International Migration Review, 18(2), 188-216. https://doi.org/10.2307/2545947

Yang, X. (1993). Household registration, economic reform, and migration. International Migration Review, 27(4), 796-818. https://doi.org/10.2307/2546913

Yeoh, B. S. A. (1999). Global/globalizing cities. Progress in Human Geography, 23(4), 607-616. https://doi.org/10.1191/03091329967464 
Yue, S., Wen., Y., Chen, M., Lu, G., Hu, D., \& Zhang, F. (2015). A data description model for reusing, sharing and integrating geo-analysis models. Environmental Earth Sciences, 74(19), 7081-7099. https://doi.org/10.1007/s12665-015-4270-5

\section{Polona Tominc}

Department of Quantitative Economic Analyses,

Faculty of Economics and Business,

University of Maribor

Razlagova 14, 2000 Maribor, Slovenia

polona.tominc@um.si

\section{Vit Paszto}

Department of Geoinformatics, Faculty of Science,

Palacký University Olomouc

17. listopadu 50, 77146 Olomouc, The Czech Republic

vit.paszto@gmail.com

\section{Samo Bobek}

Department of E-Business, Faculty of Economics and Business, University of Maribor

Razlagova 14, 2000 Maribor, Slovenia

samo.bobek@um.si

\section{Simona Sternad Zabukovšek}

Department of E-Business, Faculty of Economics and Business, University of Maribor

Razlagova 14, 2000 Maribor, Slovenia

simona.sternad@um.si 


\section{Integracija i primjena interdisciplinarnoga znanja iz područja ekonomije i prostorne znanosti}

\section{Sažetak}

Ovo je istraživanje nastalo zbog važnosti integracije znanja iz područja ekonomskih $i$ prostornih znanosti za studente koji moraju razmišljati $i$ djelovati $u$ interdisciplinarnim kontekstima. Sustavni pregled literature pokazao je da je ovo interdisciplinarno područje u velikoj mjeri prisutno u izvornim znanstvenim istraživanjima te je bez svake sumnje aktualno i vrijedno istraživanja. Glavni je cilj ovoga rada analizirati važne čimbenike koji doprinose izgradnji stavova studenata prema interdisciplinarnom znanju, kao i čimbenike koji utječu na njihove namjere da se u budućnosti koriste takvim znanjima i i integriraju ih. Izrađeni konceptualni model testiran je s pomoću modeliranja strukturnih jednadžbi (SEM). Rezultati istraživanja potvrđuju da je integracija znanja iz područja ekonomije i prostornih znanosti važna za studente. Kako je prikazano u radu, rezultati istraživanja imaju važne implikacije za institucije visokoga obrazovanja, za reformu i nadogradnju njihovih studijskih programa te za obrazovne djelatnike koji se bave područjima ekonomije i prostorne znanosti, kako u istraživanjima, tako i u obrazovanju.

Ključne riječi: model prihvaćanja; geoinformatika; modeliranje strukturnih jednadžbi.

\section{Uvod}

Nedvojbeno je da $u$ današnje vrijeme studenti moraju razmišljati i raditi u interdisciplinarnim kontekstima (Shen, Sung i Zang, 2015). U nekim je situacijama važno primijeniti međudisciplinarni znanstveni pristup, koji kombinira menadžment i prirodne znanosti. Primjeri se mogu naći u upravljanju prirodnim resursima (Robinson, Genskow, Shaw i Shepard, 2012), u kontekstu tržišta nekretnina (Benson, Hansen i Schwartz, 2000) ili kada se donose odluke na temelju modela geoanalize (Yue, Wen, Chen, Lu, Hu i Zhang, 2015).

Interdisciplinarno područje koje kombinira nekoliko gledišta iz ekonomskih znanosti s jedne strane, i prostorne znanosti - geografije s druge strane, područje 
je istraživanja koje se sve više širi, pokazujući potrebe društva da se upravo to područje istraži. Proveden je sustavni pregled literature i rezultata istraživanja u tom interdisciplinarnom području. Rezultati prikazani u ovome radu pokazuju da se fokus interdisciplinarne interakcije tih dvaju područja, koja smo jednom riječju nazvali „spacionomija” (riječ izvedena kombiniranjem riječi „spacijalni”/prostorni/ i „ekonomija”, u prošlosti mijenjao.

Naš je rad u temeljen na važnosti koju sposobnost integriranja znanja iz područja ekonomije i prostornih znanosti ima za studente, kako bi postali uspješni budući poslodavci, građani, poduzetnici itd. Stoga se u ovom istraživanju analiziraju bihevioralne namjere studenata da se koriste interdisciplinarnim znanjima iz područja ekonomskih i prostornih znanosti i integriraju ih. Podaci su dobiveni u sklopu Erasmus+ projekta strateškoga partnerstva pod nazivom Spacionomija, koji je počeo 2016. godine. U današnje vrijeme važnost geospacijalne komponente, koja je sastavnica većine ekonomskih podataka, brzo raste, što se također reflektira i u rezultatima istraživanja koja se navode u literaturi (Rae i Sener, 2016; Terhorst i Erkus-Oeztuerk, 2015; Agliari, Commendatore, Foroni i Kubin, 2014; Schulz i Bailey, 2014; Brouder i Eriksson, 2013; Hildreth i Bailey, 2013). To je dokaz da se dodatna vrijednost uvođenja geospacijalne komponente $u$ analizu ekonomskih podataka jako cijeni. Važan je cilj projekta Spacionomija razviti interdisciplinarne vještine studenata tako da međusobno povezuju područja ekonomije, menadžmenta i poslovne informatike s jedne strane, s područjem znanosti o geografskim informacijama (koja uključuje geoinformatiku, geografiju, prostorne informacije, daljinska istraživanja itd.) s druge strane (Jürgens, Moos i Redecker, 2018).

Spomenute bihevioralne namjere proučavane su s pomoću modela istraživanja koji se temelji na teoriji razumnog djelovanja (Fishbein i Ajzen, 1975) i modelu prihvaćanja tehnologije (Davis, 1989; Davis, Bagozzi i Warshaw, 1989) koji proučava način na koji korisnici prihvaćaju informacijske sustave. Razlog zašto smo u istraživanju primijenili teoriju razumnog djelovanja i model prihvaćanja tehnologije jest činjenica da se spacionomija uvelike oslanja na tehnologiju i računalne programe koji omogućavaju dobivanje informacija iz (velikih) baza podataka i sustava karakterističnih za spacionomiju. Korištenje različitih računalnih alata u području spacionomije - ERP-a (Planiranje resursa poduzeća), Power BI (Poslovna inteligencija) alata, SPSS-a (statistički računalni paket za društvene znanosti), nekoliko alata za dobivanje geografskih informacija (ArcGIS za stolna računala, ArcGIS Online i QGIS) - u kojima se isprepleću interdisciplinarna znanja i vještine, podržava upotrebu modela prihvaćanja tehnologije kao modela istraživanja. Integracija i upotreba interdisciplinarnog znanja spacionomije također se može smatrati upotrebom određenih informacijskih sustava.

Glavni znanstveni doprinosi ovoga rada su: (1) potvrda da je tema spacionomije relevantna i važna s obzirom na potrebe društva te tako prikazuje važne informacije za obrazovne institucije u postupku izrade kurikula, što potvrđuju rezultati sustavnog 
pregleda znanstvene literature iz ovog interdisciplinarnog područja; (2) potvrda da je važno koristiti se proširenim modelom prihvaćanja tehnologije kako bi se analizirale i predvidjele namjere studenata da se koriste interdisciplinarnim znanjem iz spacionomije i integriraju ga, što će pomoći obrazovnim institucijama da se usredotoče na relevantne i važne faktore koji utječu na namjere studenata.

\section{Pregled literature}

Prva faza uključivala je sustavan pregled literature iz toga interdisciplinarnog područja, s ciljem da se jasno ukaže na postojanje spacionomije i njezinih potpodručja. To je zahtijevalo provedbu istraživanja najutjecajnijih radova u tome području. Sustavno pretraživanje velikoga broja istraživanja provedeno je uzimajući u obzir radove na engleskom jeziku, objavljene u časopisima i navedene u Scopusu, jer se smatra da oni sadrže valjana, provjerena znanja (Podsakoff, MacKenzie, Bachrach i Podsakoff, 2005). Zatim je uslijedila daljnja analiza dobivenih 776 radova kako bi se utvrdilo bave li se oni uistinu interdisciplinarnim poljem spacionomije. Analiza je rezultirala konačnim popisom od 724 rada. 2000. godine vidi se znatan pad broja objavljenih članaka, što bi se moglo dovesti u vezu s tadašnjim općeprihvaćenim mišljenjem znanstvene zajednice tih dvaju područja (ekonomije i geografije), a koje se odrazilo u provokativnome radu Amina i Thrifta (2000). U njemu oni pozivaju "geografe da odustanu od svake nade da će razgovarati i raditi s ekonomistima”. Međutim, u razdoblju nakon 2000. godine, broj objavljenih radova se povećavao sve do 2010., a od tada je u opadanju.

Analiza citiranja radova provedena je s pomoću Scopusova alata kako bi se izdvojili radovi koji su u tome razdoblju bili najutjecajniji (Gundolf i Filser, 2013; Kraus, Filser, O'Dwyer i Shaw, 2014), a rezultirala je popisom od 57 dokumenata. Kategorije koje su uočene u tim najcitiranijim radovima, na temelju ključnih riječi koje su autori naveli, iskorištene su kao glavna tematska područja kojima se radovi bave. Osim toga, svi sažetci pažljivo su pregledani kako bi se provjerila glavna tematska područja. Na taj su način izdvojene četiri kategorije, prikazane u Tablici 1.

Rezultati pokazuju da se fokus istraživanja u području spacionomije u prošlosti mijenjao. Općenito gledajući, istraživači su se odmaknuli od manje međusobno povezanih prema višestruko povezanim temama iz obaju područja. Klaster koji kombinira ključne riječi „rezidencijalna lokacija”, „stanovanje” i ,tržište zemljištem”, predstavlja najcitiraniji rad iz 1998. godine, a citiran je 211 puta (André i Platteau, 1998). Slično tome, klaster koji sadrži ključne riječi „populacija”, „migracija” i „zaposlenje” bio je dominantan i karakterističan za godine prije novoga stoljeća. S druge pak strane, istraživanja koja kombiniraju „prostornu znanost”, ,geografiju” i „nacionalne ekonomije”,,,čvrste rezultate” i, inovacije”, pokazuju vezu između tih dvaju područja koja se spajaju u interdisciplinarno područje istraživanja, a karakteristična su za 21. stoljeće. Istraživački rad koji se najčešće citira seže u posljednju godinu 20. stoljeća (Feldman i Audretsch, 1999). Četvrti se klaster odnosi na „regionalni razvoj” $\mathrm{i}$,rast gradova”, a prisutan je u cijelom razdoblju koje analizirano. 
Pregled literature pokazuje da su potrebe društva da se istraže i razumiju međusobni odnosi između geografskih i ekonomskih aspekata pojedinaca, organizacija i društvenog okruženja široke i raznolike te zbog toga predstavljaju izazov obrazovnim institucijama kada žele kod studenata osvijestiti važnost spacijalne ekonomije.

Tablica 1

Klasifikacija najcitiranijih radova

\begin{tabular}{|c|c|c|c|}
\hline Kategorija & Rad & Časopis & Br. citata \\
\hline \multirow{21}{*}{$\begin{array}{l}\text { Prostorna } \\
\text { znanost, } \\
\text { geografija i } \\
\text { nacionalne } \\
\text { ekonomije, } \\
\text { čvrsti rezultati } \\
\text { i inovacije }\end{array}$} & Feldman i Audretsch (1999) & European Economic Review & 691 \\
\hline & Martin (1999) & Cambridge Journal of Economics & 371 \\
\hline & Boschma i Lambooy (1999) & Journal of Evolutionary Economics & 290 \\
\hline & Hanson (2005) & Journal of International Economics & 243 \\
\hline & Breschi i Lissoni (2009) & Journal of Economic Geography & 235 \\
\hline & Taylor (1996) & Environment and Planning $\mathrm{A}$ & 137 \\
\hline & Baldwin i Okubo (2006) & Journal of Economic Geography & 119 \\
\hline & Oerlemans i Meeus (2005) & Regional Studies & 103 \\
\hline & Truffer i Coenen (2012) & Regional Studies & 100 \\
\hline & Olivier i Slack (2006) & Environment and Planning A & 99 \\
\hline & McCann i Mudambi (2004) & Growth and Change & 77 \\
\hline & Bruelhart (1998) & World Economy & 67 \\
\hline & Glaeser, Rosenthal i Strange (2010) & Journal of Urban Economics & 66 \\
\hline & McCann (2005) & Journal of Economic Geography & 66 \\
\hline & Boschma i Frenken (2003) & Jahrbuch fur Regionalwissenschaft & 65 \\
\hline & Lakshmanan (2011) & Journal of Transport Geography & 59 \\
\hline & Lee (2002) & Progress in Human Geography & 55 \\
\hline & Masson i Petiot (2009) & Technovation & 54 \\
\hline & Desrochers (2001) & Review of Austrian Economics & 54 \\
\hline & Fingleton (2003) & Intern. Regional Science Review & 51 \\
\hline & Pan, Kaski i Fortunato (2012) & Scientific Reports & 50 \\
\hline \multirow{15}{*}{$\begin{array}{l}\text { Populacija, } \\
\text { migracija, } \\
\text { zaposlenje }\end{array}$} & Boyd (1989) & International Migration Review & 615 \\
\hline & Carlino i Mills (1987) & Journal of Regional Science & 254 \\
\hline & Falkenmark i Widstrand (1992) & Population Bulletin & 123 \\
\hline & Knapp i Gravest (1989) & Journal of Regional Science & 119 \\
\hline & Small i Song (1994) & Journal of Urban Economics & 105 \\
\hline & Williams, King i Warnes (1997) & Europ. Urban and Regional Studies & 91 \\
\hline & $\begin{array}{l}\text { Green, Hogarth i Shackleton } \\
\text { (1999) }\end{array}$ & Intern. Jour. of Popul. Geography & 85 \\
\hline & Alonso (1971) & Papers of the Reg. Sci. Association & 83 \\
\hline & Meyer i Speare (1985) & Economic Geography & 67 \\
\hline & Moomaw i Shatter (1996) & Journal of Urban Economics & 60 \\
\hline & Omran i Roudi (1993) & Population Bulletin & 56 \\
\hline & Fan (1999) & International Migration Review & 55 \\
\hline & Desmet i Fafchamps (2005) & Journal of Economic Geography & 54 \\
\hline & Woo i Kwang (1984) & International Migration Review & 51 \\
\hline & Salt (1988) & Geoforum & 50 \\
\hline
\end{tabular}


Tominc, Paszto, Bobek and Sternad Zabukovšek: Integration and Use of the Interdisciplinary Knowledge ...

\begin{tabular}{|c|c|c|c|}
\hline Kategorija & Rad & Časopis & Br. citata \\
\hline \multirow{10}{*}{$\begin{array}{l}\text { Rezidencijalna } \\
\text { lokacija, } \\
\text { stanovanje } \\
\text { i tržište } \\
\text { zemljištima }\end{array}$} & André i Platteau (1998) & Jour. of Econ. Behavior and Org. & 211 \\
\hline & Cervero i Wu (1997) & Environment and Planning $\mathrm{A}$ & 154 \\
\hline & Myers i Lee (1998) & International Migration Review & 82 \\
\hline & Levinson i Kumar (1997) & Growth and Change & 81 \\
\hline & Linneman i Graves (1983) & Journal of Urban Economics & 76 \\
\hline & Margo (1992) & Journal of Urban Economics & 59 \\
\hline & Rosenzweig i Wolpin (1988) & Journal of Public Economics & 59 \\
\hline & Yang (1993) & International Migration Review & 58 \\
\hline & Ford (1990) & International Migration Review & 57 \\
\hline & Farley, Richards i Wurdock (1980) & Sociology of Education & 51 \\
\hline \multirow[t]{11}{*}{$\begin{array}{l}\text { Regionalni } \\
\text { razvoj, } \\
\text { rast gradova }\end{array}$} & $\begin{array}{l}\text { Verburg, Soepboer, Veldkamp, } \\
\text { Limpiada, Espaldon i Mastura, } \\
\text { (2002) }\end{array}$ & Environmental Management & 545 \\
\hline & Lambooy i Boschma (2001) & Annals of Regional Science & 93 \\
\hline & McCann (2008) & $\begin{array}{l}\text { Cambridge Journal of Regions, } \\
\text { Economy and Society }\end{array}$ & 88 \\
\hline & Griffith (1981) & Journal of Urban Economics & 78 \\
\hline & $\begin{array}{l}\text { Sparke, Sidaway, Bunnell i Grundy- } \\
\text { Warr (2004) }\end{array}$ & $\begin{array}{l}\text { Transactions of the Institute of } \\
\text { British Geographers }\end{array}$ & 73 \\
\hline & El-Shakhs (1972) & Journal of Developing Areas & 71 \\
\hline & $\begin{array}{l}\text { Richardson, Kaiser, Edwards-Jones } \\
\text { i Possingham (2006) }\end{array}$ & Conservation Biology & 70 \\
\hline & $\begin{array}{l}\text { Cumbers, MacKinnon i McMaster } \\
\text { (2003) }\end{array}$ & Europ. Urban and Regional Studies & 63 \\
\hline & Yeoh (1999) & Progress in Human Geography & 60 \\
\hline & Parr (1985) & Journal of Urban Economics & 60 \\
\hline & Plummer i Sheppard (2006) & Journal of Economic Geography & 54 \\
\hline
\end{tabular}

\section{Model istraživanja}

U ovome smo se istraživanju koristili modificiranom inačicom modela prihvaćanja tehnologije, kako su predložili Davis, Bagozzi i Warshaw (1989). U njemu se navodi da je ponašanje ( $u$ našemu se istraživanju to odnosi na upotrebu i integraciju interdisciplinarnog znanja iz spacionomije) određeno bihevioralnim namjerama da se tehnologija koristi. Smatra se da su bihevioralne namjere određene i stavovima pojedinca prema upotrebi tehnologije i percipiranom korisnošću, tj. u našem istraživanju percipiranom korisnošću interdisciplinarnog znanja iz područja spacionomije i stavova prema njegovoj budućoj upotrebi. Percipirana lakoća upotrebe - u našem istraživanju, lakoća upotrebe i integracije interdisciplinarnog znanja iz područja spacionomije - utječe na percipiranu korisnost i stavove prema njegovoj upotrebi. U našem smmo istraživanju proširili model vanjskim faktorima koji opisuju osobne karakteristike (Krueger, Norris i Carsrud, 1993; Linan i Alain, 2015; Chirawattanakij i Ractham, 2016), što bi moglo biti bitno kada osoba stvara sliku o percipiranoj lakoći upotrebe i percipiranoj korisnosti interdisciplinarnog znanja iz područja spacionomije. 


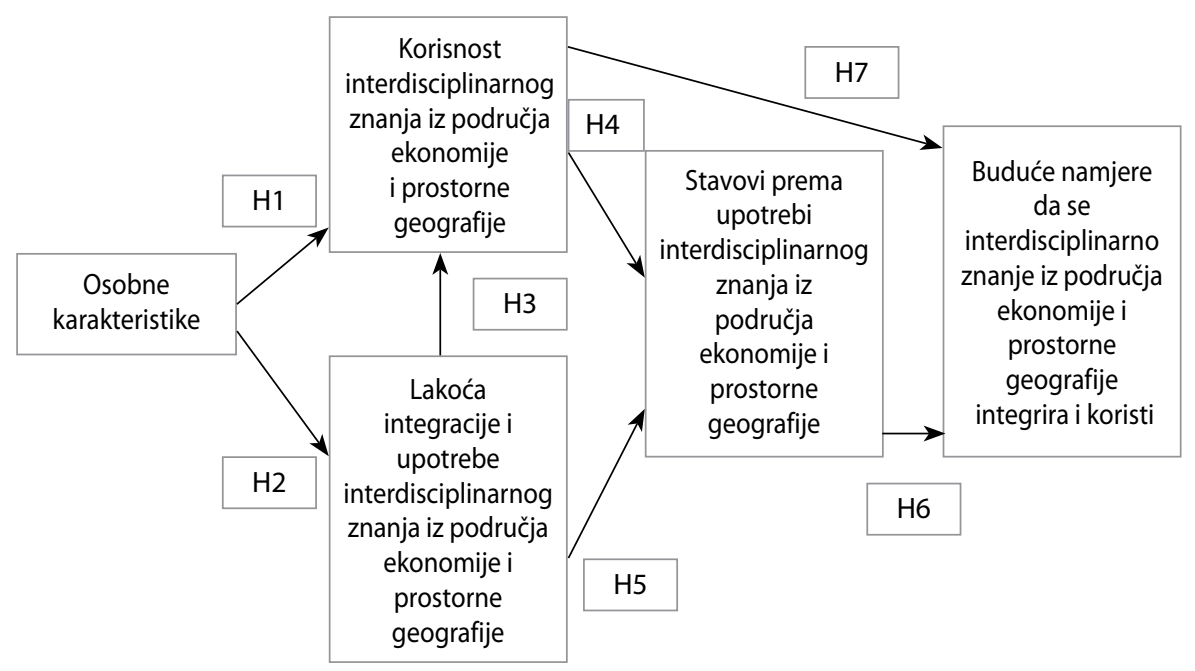

Prikaz 1. Konceptualni model istraživanja - model prihvaćanja interdisciplinarnog znanja

Konceptualni model istraživanja prikazan je na Slici 1.

Postavljene su sljedeće hipoteze:

H1. Osobne karakteristike studenata utječu na percipiranu korisnost interdisciplinarnog znanja iz područja spacionomije.

H2. Osobne karakteristike studenata utječu na percipiranu lakoću upotrebe integracije i upotrebu interdisciplinarnog znanja iz područja spacionomije.

H3. Percipirana lakoća integracije i upotreba interdisciplinarnog znanja iz područja spacionomije utječu na njegovu percipiranu korisnost.

H4. Percipirana korisnost interdisciplinarnog znanja iz područja spacionomije utječe na stavove studenata prema upotrebi toga interdisciplinarnog znanja.

H5. Percipirana lakoća integracije i upotrebe interdisciplinarnog znanja iz područja spacionomije utječu na stavove studenata prema upotrebi toga interdisciplinarnog znanja.

H6. Stavovi studenata prema upotrebi interdisciplinarnog znanja iz područja spacionomije utječu na njihove buduće namjere da to znanje integriraju i njime se koriste.

H7. Percipirana korisnost interdisciplinarnog znanja iz područja spacionomije utječe na buduće namjere studenata da to znanje integriraju i njime se koriste.

\section{Metodologija}

Sastavljen je uzorak od 99 studenata iz partnerskih institucija na projektu Spacionomija: iz dva ekonomska odsjeka (Sveučilišta u Olomoucu u Moravskoj, Češka, i Sveučilišta u Mariboru, Slovenija), odsjeka za geoinformatiku iz Sveučilišta Palacký u Olomoucu (Češka) i odsjeka za geomatiku Sveučilišta Ruhr u Bochumu 
(Njemačka).Svi su studenti ispunili online upitnik prije početka projekta Spacionomija, kako bi se dobili objektivni odgovori. Podaci su prikupljeni u razdoblju od 27. veljače do 10. ožujka 2017. godine.

Koristio se upitnik s pet mjernih skala s pomoću kojih su se mjerili konstrukti modela. Tvrdnje u konstruktima izrađene su na temelju Davisovih prijašnjih istraživanja (Davis i sur., 1989), a napravljene su izmjene kako bi model odgovarao specifičnom kontekstu interdisciplinarnog znanja, a po uzoru na istraživanja koja su proveli Park (2009), Letchumanan i Muniandy (2013) i Šebjan i Tominc (2015). Mjerna skala koja se koristila za osobne karakteristike utemeljena je na istraživanjima koja su proveli Arthur i Yuet Wong (2000); Pierce, Stacey i Barkatsas (2007); Ameen i Loeffler-Cobia (2010); Vos, van der Meijden i Denessen (2011) i Nikou i Economides (2016). Dizajn istraživanja sastojao se od sljedećih konstrukata: percipirana korisnost interdisciplinarnog znanja; percipirana lakoća integracije i upotrebe interdisciplinarnog znanja; stavovi prema upotrebi interdisciplinarnog znanja, namjera da se interdisciplinarno znanje integrira i koristi u budućnosti i osobne karakteristike kao vanjski multidimenzionalni konstrukt.

Sve tvrdnje ocijenjene su na Likertovoj skali od 7 stupnjeva u rasponu od 1 (uopće se ne slažem) do 7 (u potpunosti se slažem). Upitnik je testiran u pilot-istraživanju na skupini od 10 studenata, uz pomoć troje stručnjaka iz područja upravljanja ljudskim resursima i iz područja psihologije, kako bi se popravila struktura i vokabular kojie se u upitniku koriste.

U drugoj se fazi koristila konfirmatorna faktorska analiza unutar modeliranja strukturnih jednadžbi. Za određivanje faktorskog opterećenja indikatora koristili su se kriteriji čije su vrijednosti bile iznad 0,7 (Henseler, Ringle i Sarstedt, 2015). Prikladnost modela mjerenja procijenjena s pomoću kompozitne pouzdanosti koja se koristila za konstrukte čiji su kriteriji bili jednaki ili veći od 0,6 (Chin, 1998); vrijednosti Chronbachove alfe koje opisuju konvergentnu valjanost i pouzdanost jednaku ili veću od 0,6 (Garson, 2016) i prosječne ekstrahirane varijance kako bi se testirale i konvergentna i divergentna valjanost koja je veća od 0,5 (Chin, 1998). Ekstrahirane prosječne varijance također su se koristile kako bi se odredile diskriminantne valjanosti s pomoću Fornell-Larckerova kriterija, a kvadratni korijen ekstrahirane prosječne varijance vrijedi za bilo koju latentnu varijablu koja je veća od vlastite korelacije s bilo kojom drugom latentnom varijablom (Garson, 2016). Također je procijenjena i diskriminantna valjanost s pomoću heterotrait-monotrait omjera (HTMT) (Henseler, Ringle i Sarstedt, 2015), gdje je taj omjer ispod 1, a stroga se granična vrijednost od 0,85 koristila u prijašnjim istraživanjima (Kline, 2011). Prikladnost modela procijenjena je s pomoću standardiziranog reziduala korijena sredine kvadrata. Model je prikladan kada mu je standardizirani rezidual korijena sredine kvadrata manji od 0,10 (Garson, 2016), iako se neki koriste strožom graničnom vrijednosti nižom od 0,08 (Hu i Bentler, 1998). Strukturni koeficijenti putanje (opterećenje - standardni koeficijenti regresije) analizirani su s pomoću razine značajnosti od $0,05 . R^{2}$ vrijednosti i prilogađeni $R^{2}$ 
koristile su se za mjerenje ukupne veličine učinka modela strukturne jednadžbe, s rezultatima graničnih vrijednosti iznad $0,67,0,33$ i 0,19 , kako bi svaki od njih pojedinačno bio dostatan, umjeren i slab (Chin, 1998).

Koristio se Statistički paket za društvene znanosti (SPSS) i SmartPLS računalni program.

\section{Rezultati}

Rezultati potvrđuju opisanu jednodimenzionalnu strukturu konstrukata: percipirana korisnost interdisciplinarnog znanja; percipirana lakoća integracije i upotrebe interdisciplinarnog znanja; stavovi prema upotrebi interdisciplinarnog znanja i namjera da se interdisciplinarno znanje integrira i koristi u budućnosti, a osobne su karakteristike studenata uključene u tri dvodimenzionalna konstrukta drugoga reda: poticaj za studiranje (koji se sastoji od ambicioznosti i inovativnosti); uključenost u studij i ustrajnost (koji se sastoji od osobne motivacije i bihevioralne angažiranosti); orijentiranost prema studiju i stavovi o studiju (sastoje se od samopouzdanja u studiranju i analitičkog mišljenja te orijentiranosti na istraživanja tijekom studija).

Tablica 2 prikazuje rezultate prikladnosti modela mjerenja te upućuje na to da je kompozitna pouzdanost adekvatna. Fornell-Larckerov kriterij i korelacijska matrica varijabli prikazani su u Tablici 3 te potvrđuju diskriminantnu valjanost. Rezultati heterotrait-monotrait omjera u Tablici 4 potvrđuju diskriminantnu valjanost. Standardizirani rezidual korijena sredine kvadrata jednak je 0,096, što je prihvatljivo za preliminarni model.

Tablica 2

Kompozitna pouzdanost, Cronbachove alfe i ekstrahirana prosječna varijanca (EPV)

\begin{tabular}{|c|c|c|c|}
\hline & $\begin{array}{l}\text { Kompozitna } \\
\text { pouzdanost }\end{array}$ & Cronbachova alfa & $E P V$ \\
\hline Ambicioznost & 0,914 & 0,859 & 0,780 \\
\hline Inovativnost & 0,917 & 0,864 & 0,786 \\
\hline Osobna motivacija & 0,836 & 0,707 & 0,631 \\
\hline Bihevioralna angažiranost & 0,882 & 0,822 & 0,652 \\
\hline Samopouzdanje i analitičko razmišljanje & 0,929 & 0,913 & 0,621 \\
\hline Orijentiranost na istraživanja & 0,881 & 0,820 & 0,651 \\
\hline Korisnost & 0,904 & 0,872 & 0,612 \\
\hline Lakoća upotrebe & 0,922 & 0,887 & 0,747 \\
\hline Stavovi prema upotrebi & 0,950 & 0,930 & 0,827 \\
\hline Namjera upotrebe u budućnosti & 0,915 & 0,864 & 0,783 \\
\hline
\end{tabular}

Ispitivanje mogućnosti predviđanja endogenog konstrukta (vidi Tablicu 5) pokazuje da namjera upotrebe u budućnosti, što je primarni mjerni rezultat modela, ima vrijednost $R^{2}$, koja je gotovo dostatna - 0,580. Predviđanje stava prema upotrebi je također visoko, $\mathrm{s} R^{2}$ vrijednosti od 0,715 , a predviđanje percipirane lakoće upotrebe je nisko $\left(R^{2}=0,157\right)$. 
Statistički značajne veze imeđu konstrukata testirane su za hipoteze H1 - H7. Vrijednosti t-statistike dobivene su s pomoću bootstrap metode ponovnog uzorkovanja. U Tablici 6 su prikazani značajni koeficijenti putanje (originalni uzorak i srednji uzorak), zajedno sa standardnim devijacijama i t-statistikom.

Tablica 3

Fornell-Larckerov kriterij i korelacijska matrica varijabli

\begin{tabular}{|c|c|c|c|c|c|c|c|c|c|c|}
\hline & 1 & 2 & 3 & 4 & 5 & 6 & 7 & 8 & 9 & 10 \\
\hline 1. Ambicioznost & 0,883 & & & & & & & & & \\
\hline 2. Inovativnost & 0,583 & 0,887 & & & & & & & & \\
\hline 3. Osobna motivacija & 0,442 & 0,450 & 0,794 & & & & & & & \\
\hline $\begin{array}{l}\text { 4. Bihevioralna } \\
\text { angažiranost }\end{array}$ & 0,530 & 0,401 & 0,543 & 0,808 & & & & & & \\
\hline $\begin{array}{l}\text { 5. Samopouzdanje i } \\
\text { analitičko razmišljanje }\end{array}$ & 0,657 & 0,640 & 0,653 & 0,699 & 0,788 & & & & & \\
\hline $\begin{array}{l}\text { 6. Orijentiranost na } \\
\text { istraživanja }\end{array}$ & 0,445 & 0,479 & 0,632 & 0,445 & 0,592 & 0,807 & & & & \\
\hline 7. Korisnost & 0,450 & 0,407 & 0,455 & 0,372 & 0,412 & 0,510 & 0,782 & & & \\
\hline 8. Lakoća upotrebe & 0,230 & 0,374 & 0,223 & 0,277 & 0,381 & 0,310 & 0,573 & 0,864 & & \\
\hline 9. Stavovi prema upotrebi & 0,346 & 0,347 & 0,413 & 0,431 & 0,427 & 0,463 & 0,802 & 0,679 & 0,909 & \\
\hline $\begin{array}{l}\text { 10. Namjera upotrebe u } \\
\text { budućnosti }\end{array}$ & 0,378 & 0,342 & 0,431 & 0,343 & 0,422 & 0,419 & 0,553 & 0,711 & 0,733 & 0,885 \\
\hline
\end{tabular}

Tablica 4

Heterotrait-monotrait omjer

\begin{tabular}{|c|c|c|c|c|c|c|c|c|c|}
\hline & 1 & 2 & 3 & 4 & 5 & 6 & 7 & 8 & 9 \\
\hline \multicolumn{10}{|l|}{ 1. Ambicioznost } \\
\hline 2. Inovativnost & 0,673 & & & & & & & & \\
\hline 3. Osobna motivacija & 0,556 & 0,575 & & & & & & & \\
\hline $\begin{array}{l}\text { 4. Bihevioralna } \\
\text { angažiranost }\end{array}$ & 0,626 & 0,460 & 0,697 & & & & & & \\
\hline $\begin{array}{l}\text { 5. Samopouzdanje i } \\
\text { analitičko razmišljanje }\end{array}$ & 0,739 & 0,720 & 0,809 & 0,808 & & & & & \\
\hline $\begin{array}{l}\text { 6. Orijentiranost na } \\
\text { istraživanja }\end{array}$ & 0,526 & 0,566 & 0,835 & 0,526 & 0,676 & & & & \\
\hline 7. Korisnost & 0,512 & 0,472 & 0,577 & 0,436 & 0,461 & 0,601 & & & \\
\hline 8. Lakoća upotrebe & 0,273 & 0,426 & 0,282 & 0,313 & 0,422 & 0,358 & 0,650 & & \\
\hline 9. Stavovi prema upotrebi & 0,385 & 0,388 & 0,510 & 0,488 & 0,465 & 0,524 & 0,891 & 0,741 & \\
\hline $\begin{array}{l}\text { 10. Namjera upotrebe u } \\
\text { budućnosti }\end{array}$ & 0,436 & 0,384 & 0,548 & 0,399 & 0,475 & 0,483 & 0,832 & 0,622 & 0,775 \\
\hline
\end{tabular}


Tablica 5

Prikladnost strukturnog modela

\begin{tabular}{lcc}
\hline & R kvadrat & Prilagođeni R kvadrat \\
\hline Ambicioznost & 0,792 & 0,790 \\
Inovativnost & 0,791 & 0,789 \\
Osobna motivacija & 0,695 & 0,692 \\
Bihevioralna angažiranost & 0,839 & 0,838 \\
Samopouzdanje i analitičko razmišljanje & 0,913 & 0,912 \\
Orijentiranost na istraživanja & 0,646 & 0,642 \\
Korisnost & 0,452 & 0,435 \\
Lakoća upotrebe & 0,157 & 0,148 \\
Stavovi prema upotrebi & 0,715 & 0,709 \\
Namjera upotrebe u budućnosti & 0,580 & 0,571 \\
\hline
\end{tabular}

Tablica 6

Koeficijentiputova

\begin{tabular}{|c|c|c|c|c|c|}
\hline Veza & $\begin{array}{c}\text { Koeficijent } \\
\text {-Originalni } \\
\text { uzorak }\end{array}$ & $\begin{array}{c}\text { Koeficijent } \\
\text { - Srednji } \\
\text { uzorak }\end{array}$ & $\begin{array}{l}\text { Standardna } \\
\text { pogreška }\end{array}$ & $t$-statistika & $p$ vrijednosti \\
\hline Poticaj $\rightarrow$ Korisnost & 0,207 & 0,205 & 0,102 & 2,040 & 0,042 \\
\hline Uključenost i ustrajnost $\rightarrow$ Korisnost & 0,216 & 0,217 & 0,099 & 2,183 & 0,030 \\
\hline $\begin{array}{l}\text { Orijentiranost i stavovi } \rightarrow \text { Lakoća } \\
\text { upotrebe }\end{array}$ & 0,396 & 0,395 & 0,095 & 4,185 & 0,000 \\
\hline Lakoća upotrebe $\rightarrow$ Korisnost & 0,440 & 0,445 & 0,087 & 5,035 & 0,000 \\
\hline $\begin{array}{l}\text { Lakoća upotrebe } \rightarrow \text { Stavovi prema } \\
\text { upotrebi }\end{array}$ & 0,327 & 0,328 & 0,060 & 5,487 & 0,000 \\
\hline Korisnost $\rightarrow$ Stavovi prema upotrebi & 0,615 & 0,613 & 0,065 & 9,526 & 0,000 \\
\hline Korisnost $\rightarrow$ Namjere & 0,454 & 0,454 & 0,113 & 4,035 & 0,000 \\
\hline Stavovi prema upotrebi $\rightarrow$ Namjere & 0,347 & 0,339 & 0,111 & 3,117 & 0,002 \\
\hline
\end{tabular}

Rezultati pokazuju da poticaj studenata, kao i njihova uključenost i ustrajnost, imaju značajan i pozitivan utjecaj na percipiranu korisnost integracije i upotrebe interdisciplinarnog znanja iz područja spacionomije $(\beta=0,207$ i $\beta=0,216$, svaki zasebno). $S$ druge strane, treći konstrukt, koji se sastoji od osobnih karakteristika, orijentacije i stavova prema studiju, također ima značajan pozitivan utjecaj na način na koji studenti percipiraju lakoću upotrebe $(\beta=0,396)$. Stoga se hipoteze H1 i H2 mogu djelomično potvrditi.

Hipotetski navedeni izravni i neizravni utjecaji među konstruktima u modelu značajni su i svi su pozitivni. Percipirana lakoća integracije i upotrebe interdisciplinarnog znanja iz područja spacionomije ima statistički značajan utjecaj na način na koji studenti percipiraju korisnost $(\beta=0,440)$, kao i na stavove studenata prema interdisciplinarnom znanju iz područja spacionomije $(\beta=0,327)$. Tako su potvrđene hipoteze $\mathrm{H} 3$ i $\mathrm{H} 5$. 
Rezultati također potvrđuju i hipoteze H4, H6 i H7. Način na koji studenti percipiraju korisnost interdisciplinarnog znanja iz područja spacionomije ima izravan utjecaj na njihove namjere da to znanje upotrijebe u budućnosti $(\beta=0,454)$, što potvrđuje hipotezu H7. Međutim, percipirana korisnost također ima neizravan utjecaj na namjere studenata da se koriste znanjem iz područja spacionomije. Naime, percipirana korisnost ima značajan pozitivan utjecaj na stavove studenata prema upotrebi interdisciplinarnog znanja iz područja spacionomije $(\beta=0,615)$, čime se potvrđuje hipoteza $\mathrm{H} 4$. Stavovi imaju izravan utjecaj na namjere studenata da $\mathrm{u}$ budućnosti upotrijebe znanje iz područja spacionomije $(\beta=0,347)$. To potvrđuje i hipotezu H6.

\section{Rasprava i zaključci}

Istraživanje je potvrdilo interdisciplinarnu narav prostornih znanosti (i geografije, koja je u svojoj srži prostorna), koje se često bave pitanjima povezanima s drugim disciplinama. Ekonomska geografija, kao potpodručje ljudske geografije, nastala je potkraj 19. stoljeća. Ona i danas ostaje jednim od temeljnih potpodručja anglosaksonske geografije (Barnes, 2004), no i značajnim potpodručjem europskoga geografskog konteksta. Barnes (2004) također navodi da je ekonomska geografija „mutna i nejasna”, kada se radi o načinu na koji ona graniči s drugim disciplinama. Stoga autori ovoga rada smatraju da „čisti” geografi (i znanstvenici iz područja prostornih znanosti) i ekonomisti mogu i trebaju surađivati na zajedničkim geografskim ili ekonomskim interesima, uključujući obrazovanje mladih ljudi (studenata) u tim područjima. Štoviše, članice EU-a nalaze snažan poticaj u istraživanjima provedenima u EU i u obrazovnim mehanizmima koja im pružaju podršku u provedbi interdisciplinarnih istraživanja u razvojnim programima, uključujući istraživanja i obrazovanje (npr. Europska komisija, 2015). Prikazani rad dokazuje da je interdisciplinarna komponenta ključna u smislu prije navedenoga; štoviše, pozitivno je percipiraju mlade generacije geografa i ekonomista. To se odražava u stavovima studenata prema upotrebi i integraciji interdisciplinarnog znanja, koji utječu na njihove namjere da integriraju i koriste se interdisciplinarnim znanjem iz područja geografije i prostornih znanosti ne samo u ekonomiji nego općenito. Jedinstvena iskustva i prilike koji su nastali tijekom provedbe projekta Spacionomija mogu doprinijeti razvoju geografskog znanja kod mlade generacije ekonomista te razviti kompetencije njihovih kolega geografa (i znanstvenika iz područja prostornih znanosti).

Na području države, no jednako primjenjivo u svim državama sudionicama, implikacije ovoga istraživanja mogle bi se sažeti ovako: 1) povećana svijest o temama prostorne ekonomije (ekonomske geografije) $u$ visokom obrazovanju; 2) značajan dokaz da se interdisciplinarni pristup može koristiti i da su studenti otvoreni za suradnju u međudisciplinarnim temama i 3) autori smatraju da su i nastavnici na visokim sveučilištima i studenti konačno uhvatili zalet kako bi stvorili neke nove ideje i znanja, što ukazuje na interdisciplinarnu narav geografije. Naše je istraživanje također 
potvrdilo rezultate istraživanja navedenih u literaturi i usmjerenih na analizu održivog razvoja. Ta istraživanja naglašavaju važnost kombiniranja ekonomskih, socijalnih, prostornih i ekoloških stajališta (Vintar Mally, 2018), jer je prepreka održivom razvoju utjecaj suvremene ljudske ekonomske aktivnosti na prostorne elemente (Đukičin, Đorđević i Milanković 2014). Ta istraživanja također navode da, osim određivanja i geoprostornih karakteristika i njihova označavanja na karti, geoprostorni podaci moraju biti dodani socioekonomskim i demografskim podacima kako bi mogli olakšati informirano donošenje odluka kod donositelja politika.

Naše istraživanje također ima i ograničenja koja istodobno otvaraju mogućnosti za daljnja istraživanja, pogotovo kada se radi o implikacijama za obrazovne djelatnike. Kako u današnje vrijeme studenti moraju razmišljati izvan okvira uže discipline koju studiraju te kako moraju steći kompetencije razmišljanja i rada u međudisciplinarnim područjima, važno je pitanje kako u obrazovni sustav uvesti učinkovito interdisciplinarno razmišljanje i komunikaciju. Erasmus+ projekt strateškog partnerstva pod nazivom Spacionomija, u sklopu kojega je ovo istraživanje provedeno, nudi jedinstvene mogućnosti za razvoj specifičnih pristupa poučavanju i učenju unutar interdisciplinarnog područja ekonomije i geografije kao prostorne znanosti. Buduće godine rada na projektu s većim brojem uključenih studenata omogućit će ponovno testiranje kako bi se utvrdilo postoje li važne razlike među studentima s obzirom na percipiranu korisnost, lakoću upotrebe i stavove prije i nakon sudjelovanja u projektu Spacionomija. To će nam pomoći da testiramo prikladnost nastavnih pristupa i pristupa učenju (utemeljenih na hibridnom učenju, engl. blended learning i fokusiranih na igre simulacije). Testiranje razlika među studentima obaju područja - ekonomije i prostorne znanosti, geografije - također je važan zadatak u budućnosti projekta. Ako razlike postoje, možda je raznovrstan pristup obrazovanju važan faktor koji utječe na uspješnu provedbu međudisciplinarnih pristupa.

$S$ druge strane, i obrazovni djelatnici također mogu naići na prepreke pri integriranju ekonomije i geografije kao prostorne znanosti. Robinson, Genskow, Shaw i Shepard (2012) primijenili su teoriju planiranoga ponašanja kako bi odredili i opisali faktore koji mogu predvidjeti namjeru praktičara da se društvene znanosti integriraju u upravljanje prirodnim resursima. Iako se svakodnevni rad i aktivnosti praktičara mogu razlikovati, nastavnici/obrazovni djelatnici mogu naići na slične prepreke kada se ekonomska stajališta i geografija kao prostorna znanost moraju integrirati u studijskim programima. Slično rezultatima istraživanja koje su dobili Robinson, Genskow, Shaw i Shepard (2012), na odluke nastavnika da uključe interdisciplinarne aspekte može utjecati njihovo samopouzdanje da mogu integrirati ta područja, kao i njihova uvjerenja da će rezultati takve integracije dovesti do vrijednih i dobrih rezultata učenja. Buduće godine projekta Spacionomija pružit će priliku i za analizu tih aspekata.

Da zaključimo, rezultati istraživanja potvrđuju važnost integracije znanja iz područja ekonomije i prostorne znanosti za studente koji u današnje vrijeme moraju razmišljati 
i djelovati na interdisciplinaran način. Kako je prikazano u radu, rezultati istraživanja imaju važne implikacije za institucije visokoga obrazovanja i za reformu i nadogradnju njihovih studijskih programa. Također su važni i za obrazovne djelatnike u područjima prostornih i ekonomskih znanosti, kako u istraživanjima, tako i u obrazovanju.

\section{Zahvala}

Ovaj rad proveden je u sklopu projekta br. 2016-1-CZ01-KA203-024040 Prostorno iskorištavanje ekonomskih podataka: metode interdisciplinarne analitike (Spacionomija), koji je financiran sredstvima Europske unije u sklopu Erasmus+ programa. 